\title{
ERRATA
}

The article on page 211, The Floating Trust: Mutual Wills should be corrected as follows. On page 211, the second paragraph, third sentence, insert A for between the words "for" and "life"; thus reading ". . . a trust for $A$ for life, ...." The page number in footnote 26 should be 385 . The third quotation on page 233 (footnote 105) should have inserted after the second "inter vivos" the following words: is, therefore, not unqualified. If the survivor's power of appointment inter vivos. . . . Also, the quotation should end after the word "unqualified." Footnote 136 should be [1972] Ch. 698. 


\section{THE FLOATING TRUST: MUTUAL WILLS}

\section{A. SHERIDAN*}

In order to give effect to a testator's intention equity has recognized the coniept of the trust of fluctuating property. The writer discusses this concept within the framework of the law relating to mutual wills. He begins by con:idering when wills are mutual wills giving rise to a trust. He continues with $a$ discussion of the extent to which the parties are then restricted in maling further wills effective to dispose of the beneficial interest in their property and concludes with a consideration of when the trust starts to operate including what property is subject to the trust and what powers of disposition inter vivos are removed from the testators who make the mutual wills.

\section{INTRODUCTION}

For more than two centuries equity has known and blessed a trust of fluctuating property. At the inception of the trust there is a corpus, which may not even be the subject of an inventory, from which the trustee may make appropriations to his own use as if his legal title were fettered by no trust, and to which, in some cases, anything the trustee acquires becomes an accretion, during the floating stage of the trust. Typically the first trustee is the tenant for life, whose death causes the trust to crystallize on the property to which he holds the title when he dies. Now the remainderman comes into his own. Yet during the period when the trust was floating he had rights and remedies, undemolished by uncertainty of subject-matter, not aborted by repugnancy of the power of free disposal of capital to the status of an equitable tenant for life.

There are many possible variations. The typical kind may be stated in ordinary language as absolute or fee simple ownership of property except that the owner cannot leave it by will (except to the remaindermen in accordance with the floating trust) and except that if the owner dies intestate the property passes, not to his next of kin, but to those $r$ maindermen. To answer the objection that there cannot be a remainder after absolute ownership or after a fee simple, the typical case may be stated in legal language as a trust for life, and as to capital (or fee simple), on trust for such person or persons or charity or charities as A may, by disposition inter vivos, at his absolute discretion appoint, and on A's death, in default of appointment, on trust for the remaindermen absolutely (or in fee simple). The trustee may or may not be or include the teneint for life; the tenant for life's power of appointment may be general (as to inter vivos appointments) or limited as to purpose (e.g. for his reasonable maintenance) or method (e.g. by sale but not gift). In jurisdictions which allow legal life estates, legal powers and legal fee simple remainders, there need not even be a trust.

Such life estates or interests coupled with a power to dispose of or consume the fee simple or capital are often expressly created as in Montreal Trust Co. v. Tutty, ${ }^{1}$ but in many other cases a clear intention to achieve the same effect is frustrated on some technical objection by

\footnotetext{
* LL.D. (London), Ph.D. (Belfast), of Lincoln's Inn, Barrister-at-Law; Professor of Law, University College, Cardiff, and visiting Professor of Law, 1976-77, University of Manitoba.

1 (1ฐ50) 25 M.P.R. 121
} 
the court as in Re Hornell. ${ }^{2}$ Kennedy discussed those cases fully in his article Gift by Will to W: At Her Death "What Remains" to the Children, but a quarter of a century has gone by, and there are more of them now. What the courts often strike down is a bequest such as: "I leave all my property to my wife, and if there is any of it left at her death, that is to go to my daughter." There can be no doubt what the testator intended and, the disposition being by will, that is all that matters if it is possible to give effect to it. The tendency to say that the widow gets either a life interest (in which case it must all be left at her death) or an absolute interest (in which case she may leave it by will to someone other than the daughter), and thereby to defeat part of the intention of the testator, is perhaps due in part to failure to appreciate that the middle course (a life interest with a power of appointment and a gift over of what is not appointed) is exactly how the courts have construed a gift without any express reference to life, but followed by a gift over of what remains at the death of the donee, in cases of mutual wills.

Writers on mutual wills have often drawn attention to the legal difficulties involved. "If ever there was a manner in which wills should not be drawn this is it."4 But they continue to be drawn in that manner, despite lawyers' theoretical anguish. Mitchell, in his article Some Aspects of Mutual Wills, ${ }^{5}$ showed how many problems were raised by mutual wills and yet had not been the subject of judicial discussion (at least in England or other major Commonwealth jurisdictions). He gave good advice on how to draft such arrangements, and perhaps his advice has been taken because there has not been much reported litigation on mutual wills since he wrote (at least in England or other major Commonwealth jurisdictions). Some of the problems writers mention, and some of the difficulties judges think they have, may be due, at least in part, to failure to appreciate fully the nature of the floating trust and how flexible an institution it is, whether the trust be express, implied or constructive. For example, the answer to the question of when a trust starts to float is bedevilled by the erroneous assumption that all trusts start floating at a time selected by a single criterion; the answer to the question of how property may come into or go out of the trust is obscured by the belief that it happens in the same way from one floating trust to another; finally, the close association of floating trusts with mutual wills, ever since the first trust arising out of mutual wills was declared in Dufour v. Pereira, ${ }^{6}$ is not to the exclusion of fixed trusts under mutual wills.

The first step in recognizing the floating trust, analyzing it, differentiating it from its fellow trusts which do not float and considering its usefulness, is a brief restatement of the law of mutual wills. Mutual wills are wills made by two people (whether in a single document, called a joint will, or in separate documents) which give rise to a trust which restricts the parties in the extent to which they can effectively dispose by later will of the property subject to the trust. That is the minimum. The trust may also restrict the extent to which the parties can dispose of the property inter vivos. It is now proposed to

\footnotetext{
2 [1945] \& D.L.R. 440.

3 (1950) 28 Can. Bar Rev. 839.

- Waters, Law of Trusts in Canada 352 (1974).

3 (1951) 14 Mod. L. Rev. 136.

6 (1769) Dick. 419.
} 
consider, first, when wills are mutual wills giving rise to a trust; secondly, the extent to which the parties are then restricted in making further wills effective to dispose of the beneficial interest in their property; thirdly, when the trust starts to operate, which includes consideration of what property is subject to the trust and what powers of disposition inter vivos are removed from the testators who make the mutual wills.

\section{MUTUAL WILLS GIVING RISE TO A TRUST}

Rule 1: The trust arises only if there is a contract between the two testators to the effect that neither shall alter the proprietary dispositions made in his will without the consent of the other (except to the extent the contract permits). That was one of the grounds for the decision in Lord Walpole v. Lord Orford ${ }^{7}$ that there was no trust, though there is a strong case made that there was a contract in that case in Hargrave's Juridical Arguments. ${ }^{8}$

Rule 2: Such a contract, like any other contract, to be valid must be certain in its terms. That was another ground of the decision in Lord Walpole v. Lord Orford, and was referred to by Ashbury J. in Re Oldham.9

Rule 3: Such a contract is not to be inferred merely from the existence of wills in reciprocal terms.

This rule is controversial and requires further consideration. By "reciprocal wills" is meant wills which are wholly or nearly identical mutatis mutandis. For example, a testator leaves all his property to his wife for: life, with remainder to their children equally, while the wife leaves all her property to her husband for life, with remainder to their childrer. equally; or husband and wife make a joint will which, after pecuniary legacies, provides: "we leave the residue of our property to the survivor: of us, and what is left on the death of the survivor is to be divided equally among our nephews and nieces."

It would be an unjustifiable and deplorable intrusion of the law to treat the mere makirg of simultaneous and identical wills by such a husband and wife-even though the w:lls disposed of jointly owned property-as a legally binding contract.

So said Ungoed-Thomas J. in Vine v. Joyce, ${ }^{10}$ in holding there was no trust and that therefore the survivor, the wife, could make a new will disposirig effectively of the beneficial interest in the property concerned. That was also one of the grounds of the decision in Lord Walpole v. Lord Orford." In Re Oldham, ${ }^{12}$ husband and wife made wills, each giving property (residue under the husband's will, everything under the wife's will) to the other "absolutely," with the same provisions in case of lapse. The husband died first, his will unchanged. The wife took his residuary property. Years later, she remarried and made a new, entirely different, will. A few months later she died. It seems that over $90 \%$ of the property to which she had title at death was derived from her first husband's estate. There was no evidence, apart from the wills

\footnotetext{
3 (1797) 3 Ves. 402.

8 Vol. 2 at $272-286$.

${ }^{9}$ [1925] Ch. 75 at 87 .

10 (1963) The Times 24 th October.

11 Sicpra, n. ?.

12 Sitpra, n. 8.
} 
themselves, of an agreement that the arrangement should be irrevocable, or a trust. Counsel for the plaintiff contended ${ }^{13}$ that, as a result of the two original wills, the wife "must not make a testamentary disposition of her property inconsistent with part two [the provisions in case of her husband predeceasing her] of her mutual will, though of course she could dispose of her whole property inter vivos, an unlikely risk neither contemplated nor provided against." Astbury J. held that the mere agreement to make mutual wills, doing it, the death of the husband with his will unchanged and the acceptance by the wife of her husband's residuary estate did not impose a trust on any property owned by the wife at her death. He said: ${ }^{14}$

In order to enforce the trust for which the plaintiff contends I must be satisfied that its terms are certain and unequivocal and such as in the circumstances $I$ am bound to give effect to. What is the evidence of that? Of course it is a strong thing that these two parties came together, agreed to make their wills in identical terms and in fact so made them. But that does not go nearly far enough.

And he added ${ }^{15}$ that the parties might well have envisaged different arrangements had circumstances changed, so it was not clear that they intended to bind themselves that the dispositions would be irrevocable by the survivor. There does not appear to be any English dissent from that principle. In Dufour v. Pereira itself, Lord Camden required no evidence of a contract outside the joint will, ${ }^{16}$ but that could mean no more than that the will in that case showed there was a contract. The Lord Chancellor said: "The instrument itself is the evidence of the agreement. ...."

In Canada (as in Australia) there is weighty support for the view set out in the rule, but there is also authority to the contrary.

Rose J., in Re Hackett, ${ }^{17}$ held that a contract for irrevocability could be inferred from the terms of the will. Masten J., in Re Payne, ${ }^{18}$ decided in the same way, and an appeal was dismissed;19 so did Schroeder J. in Re Kerr, ${ }^{20}$ and an appeal was again dismissed. ${ }^{21}$ These, too, may be no more than decisions that such contracts could be inferred from those particular wills.

In the British Columbia case of Re Skippen, ${ }^{22}$ where he held that there was evidence, in the wills and elsewhere, of a contract to make the arrangement binding, Coady J. said obiter: ${ }^{23}$

The law . . seems clear, that the making of the mutual wills is not of itself sufficient to establish the agreement; it must be shown that there was an agreement that each party was to be bound; in the absence of such an agreement, the survivor is not bound.

In the Nova Scotia case of Re Creelman ${ }^{24}$ husband and wife made a joint will giving property to the survivor of the testators for life, with remainders over. The wife died, the husband took under her will, and

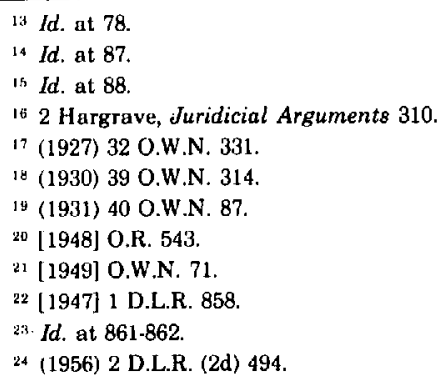


then he made a new will leaving the property in a different way. When the husiband died, Doull J. held, the legatees in remainder under the joint will were not the beneficiaries under any trust. There was no evidence of a contract between the husband and wife not to revoke the arrangement, and there was no difference as to the requirement of such a contract between a joint will and separate mutual wills. The last proposition is often put forward since Hargrave first did so, ${ }^{25}$ and should be correct, though it is interesting that Re Hackett, Re Payne and Re Kerr were all cases of joint wills. In Pratt v. Johnson, ${ }^{26}$ too, husband and wife made a joint will. Although the judges of the Supreme Court of Canada disagreed in that case as to whether there was a trust, they all seem to have taken the same view of the law. Cartwright J., in a dissenting judgment with which Rand J. agreed, held that there was no trust because there was no evidence of an agreement that the arrangement in the joint will should not be revoked. He said:27

The question is not whether [the parties] agreed to make their wills in identical terms mutatis mutandis-it may be assumed that they did-but rather whether the evidence establishes an agreement that the wills so made should not be revoked. . . . the fact that the two wills were made in one document and in identical terms does not necessarily connote any agreement beyond that of so making them. . . .

Earlier, the learned judge had said:28

In so far as any of these cases [the Ontario decisions in Re Hackett, Re Payne and Re Kerr] decide that the mere circumstance of two persons making a joint will or making mutucl wills is in itself evidence of an agreement not to revoke the wills they ... . ought not to be followed.

Locke J., with whom Kerwin C.J.C. and Martland J. agreed, held that, on the basis of the will itself and of the surviving wife's affidavits made in earlier litigation, there was such an antecedent agreement as to give rise to a trust. In Re Gillespie ${ }^{29}$ there was a stark split in the Ontario Court of Appeal, the majority clearly disagreeing with the opinion of Cartwright J. in Pratt v. Johnson. Once again, the court was considering whether a joint will by husband and wife gave rise to a trust. Kelly J.A., with whom McLennan J.A. agreed, began in orthodox fashion by saying: ${ }^{30}$ “. . . an agreement to make mutual wills cannot be inferred from the similarity of the documents." Then he produced a doctrine which is either wrong or special to Ontario by continuing:

Such, however, is not the case where both testators sign the same will as a joint document. Since each signing party must be presumed to have been fully aware of the contents of the document and to have signed it meaning that its contents express his desires and intentions, in my opinion solely through reading the terms of a joint will it may he possible to prove the existence at the appropriate time of the agreement [that the survivor shall not revoke the joint will].

That is a non sequitur. Certainly the will may show there was a contract not to revoke it; but equally certainly the fact that a person knew and intended what was in his will is no evidence at all that he bound himself not to give effect to a change of mind. Some more of Kelly J.A.: ${ }^{31}$

\footnotetext{
25 Supra, n. 16 at 311 .

${ }^{26}$ (1958) 16 D.L.R. (2d) 383.

27 la. at $401-402$.

23 la. at 401 .

${ }^{2 y}$ [1969) 1 O.R. 585 .

3u Io. at 587 .

31 la. at 589 .
} 
Such an agreement [viz. to embody a scheme in a joint will] by necessary implication embodied an agreement that the disposition settled upon should not be revoked as revocation by either party would completely frustrate the scheme upon which they had agreed.

Most of that is refuted in the dissenting judgment of Laskin J.A., but two comments seem called for before referring to his opinion. First, revocation would only frustrate the scheme if the scheme did not comprise revocability as one of its elements: it is not possible to deduce that an irrevocable scheme was intended from the proposition that an irrevocable scheme would be frustrated by revocation. Secondly, the reference to either party is surprising because it is usually only revocation by the survivor that is nullified by the finding that there is a trust. Laskin J.A. held there was no evidence of agreement such as was necessary to support a trust. In his view ${ }^{32}$ the use by the testators of a single document for a disposition pooling their assets showed no more than an arrangement for similar dispositions under a single document. The learned judge, who cited passages with approval from judgments in the High Court of Australia in Birmingham v. Renfrew ${ }^{33}$ and from the judgment of Cartwright J. in Pratt v. Johnson, said: ${ }^{34}$

We are being asked to interfere with the operation of a validity executed will [by the surviving husband, revoking the joint will], which has been admitted to probate, on the basis of an agreement of which there is no memorandum in writing and which is given the additional effect of severing a joint tenancy of land. Moreover, we are being asked to do this in favour of persons not parties to the agreement who are unable to produce any evidence of its mere existence, let alone its binding force.

That reference to interference, echoing Ungoed-Thomas J.'s "intrusion" in Vine v. Joyce, recalls that a will is in principle revocable; and husband and wife should not be deterred from agreeing on the terms of their will for fear that they are unintentionally signing away their right to change their minds in the light of changing circumstances.

In Australia, the law was clearly stated as to separate mutual wills (joint wills not not seem to have been before the courts) by the Privy Council in Gray v. Perpetual Trustee Co. Ltd. ${ }^{35}$ on appeal from New South Wales. Their lordships approved Re Oldham and Ashbury J.'s reasoning, the facts being similar except that the parties gave each other only life interests and that the occasion for the making of a new will by the surviving wife was not her remarriage. Viscount Haldane, giving the advice of the Judicial Committee, said: $:^{36}$

... the mere fact of making wills mutually is not . . . evidence of such an agreement [i.e., an agreement to constitute equitable interests in remaindermen] having been come to. And without such a definite agreement ther can no more be a trust in equity than a right to damages at law.

In Birmingham v. Renfrew, ${ }^{37}$ there was an oral contract between husband and wife, in pursuance of which they made mutual wills, each leaving property to the survivor, and the survivor leaving the property to named persons. The wife died and the husband took under her will, after which he made a new will disposing of his property in a different way. It

\footnotetext{
d2 Id. at 594-595.

33 (1937) 57 C.L.R. 666.

34 Supra, n. 29 at 594.

35 [1928] A.C. 391.

36 Id. at 400.

37 Supra, n. 33
} 
was decided that the property was held on trust for the persons named in the rnutual wills. Latham C.J. struck a note of caution ${ }^{38}$ with which Dixon J. specifically agreed, ${ }^{39}$ Evatt J. concurring in the result:

There was evidence which, if believed, justified the learned judge in finding that the existence of the agreement ... [to make and not revoke the wills] was established. Those who undertake to establish such an agreement assume a heavy burden of proof. It is easy to allege such an agreement after the parties to it have both died, and any court should be very careful in accepting the evidence of interested parties upon such a question. Perhaps most husbands and wives make wills 'by agreement,' but they do not bind themselves not to revoke their wills. They do not intend to undertake or impose any kind of binding obligation. The mere fact that two persons make what may be called corresponding wills in the sense that the existence of each will is naturally explained by the existence of the other will is not sufficient to establish a bindir.g agreement not to revoke wills so made. . . .

Rule 4: Such a contract is as effective when made after the execution of the wills as when made before or contemporaneously with the wills. That wias so decided by Ferguson J. in $R e$ Fox. ${ }^{40}$ In that case, after husband and wife had made wills in reciprocal terms they agreed with each other that the husband could make a change in his will and that, if he did, the wife would make a complementary change in hers. The husband made that change. On his death, the wife took under his will but herself died without changing her will in the manner agreed. The learned judge held that the terms of the trust of the wife's estate were to be what they would have been if she had changed her will in the way she had contracted to do.

Rule 5: Such a contract is effective even if it does not relate to wills in reciprocal terms. In Williams $\mathrm{v}$. Williams, ${ }^{41}$ husband and wife, in pursuance of a contract between them, made a joint will by which the husbancl left his property to $A$ and the wife left her property to $B$. The wife having died, the Supreme Court of Appeals of Virginia held that the husband could not effectively give his property to anyone but $\mathrm{A}$.

Rule 6: Such a contract is not confined to husband and wife. In Lord Walpole v. Lord Orford ${ }^{42}$ the reciprocal wills were made by a man and his great uncle. There was held to be no trust because of lack of evidence that there was a contract, but the only significance of how the parties were related to each other lay in the extent to which such factors as their great disparity in age made it less sensible to infer that they had made a contract for unequal chances. There was held to be a trust in Allen v. Ross, ${ }^{43}$ the mutual wills before the Supreme Court of Wisconsin being made by mother and daughter (the daughter died first).

Rule 7: Even if the arrangement relates to land, there is no need for the contract or the trust to be evidenced in writing. That, at least, is the position on the American and Australian authorities.

In Carmichael v. Carmichael, ${ }^{44}$ there was an oral agreement for mutual wills by husband and wife and the wills were duly made. The husband having died and the wife having taken under his will, the Supreme Court of Michigan held that the arrangement was enforceable

\footnotetext{
38 Id. at $674-675$.

${ }^{39}$ Id at $681-682$.

0 [1951] O.R. 378.

496 S.E. 749 (1918).

12 (1797) 3 Ves. 402.

$4322 E$, N.W. 831 (1929).

4440 N.W. 173 (1888).
} 
against the wife in respect of land without any writing: the case was taken out of the Statute of Frauds by the fraud that would be involved in the wife violating the agreement. The court of Civil Appeals of Texas came to a similar conclusion in Larrabee v. Porter, ${ }^{45}$ as did the Supreme Court of Iowa in DeJong v. Huyser. ${ }^{46}$

Both the husband and the wife in Birmingham v. Renfrew ${ }^{4}$ had real property. The High Court of Australia, holding there was a constructive trust, rejected the argument based on the Statute of Frauds. In the words of Latham C.J.:48

The defendants also relied upon the provision of the Property Law Act, sec. 53, requiring trusts of land to be manifested in writing. This section, however, does not apply to constructive trusts (sub-sec. 2), and for this reason it cannot be relied upon as a defence to this action. The trust relied upon in this case is not an express trust which the husband created. The only trust alleged is a trust which is declared by the law to affect the conscience of his executor and of the volunteers who are devisees or legatees under his will. [I.e., the will inconsistent with the earlier mutual wills.]

\section{RESTRICTION BY THE TRUST OF FUTURE TESTAMENTARY DISPOSITION}

While both testators are alive there is no question that can arise, but as soon as one dies a question may crop up if one has altered his will so that his last will does not make the dispositions required by the contract between the parties. Whether there is any trust imposed upon his estate in favour of the surviving testator or in favour of a third party depends on the circumstances.

First, the parties can revoke the arrangement by agreement, as with any contract,and if that is done it cannot thereafter bind anybody. That was said obiter by Lord Camden in Dufour v. Pereira, ${ }^{49}$ and has never since been doubted.

Secondly, it is said that one can revoke the arrangement if he gives notice to the other (Dufour v. Pereira ${ }^{50}$ ), but not secretly (Dufour v. Pereira $^{51}$ and the New Zealand case of Crichton v. Public Trustee, ${ }^{52}$ per Reed J.). What Lord Camden said was: ${ }^{53}$

A mutual will is a revocable act.-It may be revoked by joint consent clearly.-By one only, if he give notice, I can admit. But to affirm, that the survivor (who has deluded his partner into this will upon the faith and persuasion that he would perform his part) may legally recall his contract, either secretly during the joint lives, or after at his pleasure; I cannot allow.

The existence of any power to revoke at all may seem strange, because there is a contract. In fact, it requires several different situations to be distinguished:

(a) Husband and wife contract that each will leave all his property to the other for life, with remainder to their children equally. Mutual wills are made accordingly. Later, the husband makes a new will, revoking the earlier one and leaving all his property to his

\footnotetext{
45166 S.W. 395 (1914)

4H 11 N.W. (2d) 566 (1943).

${ }^{47}$ Supra, n. 33.

48 Id. at 680 .

${ }^{4 y}$ (1769) Dick. 419 at 420 .

su Id.

s) Id, at 421 .

32 [1939] G.L.R. 36 at 39

5:3 2 Hargrave, Juridicial Arguments 308.
} 
grandchildren equally, and he tells his wife what he has done. The wife raises no objection but leaves her own will unchanged. The husband dies. The children have no claim on the husband's estate. Being third parties so far as the contract is concerned, they fail unless they can establish a trust. There is no trust for them apparently because: (i) the husband provided no express testamentary trust for them; (ii) if there is an incompletely constituted trust the children are volunteers and the only person (the wife) who gave consideration has chosen not to enforce the complete constitution of the trust; (iii) there is no implied trust because there was no intention of the parties that could support it; (iv) there is no constructive trust because the husband has perpetrated no fraud.

(b) Keep the circumstances as in (a), except that the wife changes her will to leave all her property to her grandchildren. The children have no claim on her estate either.

(c) Keep the circumstances as in (a), except that the wife does object. After her husband's death, she brings an action for specific performance of the contract against his personal representatives, and for damages in so far as the contract is not specifically enforceable. If she succeeds, she will presumably have set up a trust of her husband's property and of her own for the children as effectively as if the husband had never altered his will, for the children's remainder under the husband's will is included in what she sued for and their remainder under her will is secured by a constructive trust to prevent the fraud she would do if she took the benefit and tried to duck the burden.

But will she succeed? There is a contract. But is there an implied term that one party may revoke provided he gives the other a chance to do so? The obiter dictum in Dufour v. Pereira suggests that there is. That is strongly supported by Stone v. Hoskins. ${ }^{54}$ Gorrell Barnes P. held that the revocation by the first testator to die was valid, and that hence the survivor could claim no part of his estate, even though the survivor did not learn of the revocation until the other testator was dead. The learned Presiderit said:55 "The only object of notice is to enable the other party to the bark;ain to alter his or her will also, but the survivor in the present case is not in any way prejudiced. He has notice as from the death." But an implied term cannot co-exist with an express term to the contrary. As contracts not to revoke wills are valid and enforceable in general, there is no reason to believe that a contract for mutual wills could not exclude the right of one party to revoke on notice to the other. Such a contract would seem to create a trust from the moment the contract is entered into, so far as the contract is one of which specific performance can be granted; but to the extent that specific performance is not available, the survivor's action for damages is the only consequence of breach. However, the bringing of a successful action for damages would presumably create a constructive trust for the remaindermen of the plaintiff's property, again on the footing of preventing the fraud she would do if she took the benefit of the bargain and tried to avoid the burden. 
(d) Husband and wife contract that each will leave all his property to the other for life, with remainder to their children equally. Mutual wills are made accordingly. Later, the husband makes a new will, revoking the earlier one and leaving all his property to his grandchildren equally. The husband dies, whereupon the wife learns for the first time of the husband's later will. She then makes a new will similar to the husband's later one. The children have no claim on either the husband's estate or the wife's.

(e) Keep the circumstances as in (d), except that the wife decides not to alter her will. The position is the same as to the children's lack of claim on the husband's estate (though of course they will take under the wife's will).

(f) Keep the circumstances as in (d), except that the wife, on learning of the husband's later will, dies of shock. She has not in fact had the chance to alter her will referred to in Stone v. Hoskins, so there ought on principle to be a trust of the husband's estate for the children (who take under the wife's will).

(g) Keep the circumstances as in (d), except that when the wife learns of her husband's later will she sues his personal representatives. The reasoning under paragraph (c), ante, should apply, and the outcome should depend on whether it was a term of the contract between husband and wife that neither party should revoke even on notice to the other.

Thirdly, one must consider the power, if any, of the survivor to alter his will effectively if the other testator has died leaving as his last will the one made in accordance with the contract for mutual wills. There has been some debate as to whether a trust of the survivor's property arises on the death of the other testator (by virtue of the extinction of the dead testator's chance of changing his mind) or whether the trust comes into existence on the survivor taking whatever property is left to him by the will of the other testator (by virtue of the fraud it would be for the survivor to accept the benefit of the bargain and reject the burden). That debate is allied to another: whether the trust is implied or constructive, which is sometimes perceived as an arid debate because it appears to involve a distinction without a difference. In so far as it is assumed that there is a correct date which marks the commencement of all trusts arising out of mutual wills, the debate is misdirected because the assumption is unfounded. So is the debate about implied and constructive trusts. The origin of the trust lies in the agreement between the parties and the wills they make in accordance with that agreement. The terms, express or to be gathered by implication, of the arrangement between the parties are variable. A trust may arise at any time, either as required by the agreement or to prevent fraud by the survivor. Some such trusts come into existence when the first testator to die does so; some when the survivor accepts benefits under the other testator's will; some not until the survivor dies. It is quite easy to determine the correct date for any particular trust by regard to the terms of the arrangement (particularly what property it covers and what dispositions of that property it requires) and to the application of principles of equity to the acts of the survivor after the other testator has died. Despite dicta which can be misleading out of context; this general statement and the hypothetical examples given later are consistent with the actual decisions of courts and the reasons given for them. 
It cannot be emphasized too often that the circumstances of mutual wills are highly variable; so the examples which follow must be regarded as no more than basic models. ${ }^{55}$

(a) Husband and wife contract that each will leave all the property he owns when he dies to the other absolutely, and that the survivor will leave any property he owns when he dies to their only child absolutely. Mutual wills are made accordingly. The hissband dies, having made no subsequent will and without revoking the contractual one. The wife does the following things: (i) declines to accept a portrait of Mao Tse Tung, one of the items in her husband's estate; (ii) takes the rest of her husband's property; (iii) sells shares she inherited from her husband and spends the proceeds on a holiday in Australia; (iv) gives away her jewellery to her niece; (v) makes a will leaving half her property to her niece and half to her child. As the agreement related to property each testator owned at death, with no obligation to own anything in particular at death, the wife's transactions (i) to (iv) are valid and effective. Transaction ( $v)$ is contrary to the agreement, which created a trust of the wife's property at death for the child, so the wife's personal representatives hold her whole estate for the child.

(b) Husband and wife contract that each will leave all the property he owns at the date of the contract, together with any property he acquires later, to the other "absolutely," and that the survivor will leave all such property to their only child absolutely. Mutual wills are made accordingly. The husband dies, having made no later will and without revoking the contractual one. The wife accepts what is left to her by her husband's will. There is now a trust. Not only is the wife disabled from diverting any of her property (whether derived from her husband's estate or not) from the child by will: she is also only a tenant for life of her late husband's property, and of all her other property, the child having a vested remainder subject only to any express or implied power of appointment (such as to resort to capital if necessary for her maintenance) derived from the contract with her husband and the mitual wills made in accordance with it.

(c) Husband and wife contract in the same way as in (b), and mutual wills are made accordingly. The husband dies, having made no later will and without revoking the contractual one. The wife disclaims all interest in her husband's estate, which then goes to the child as his next of kin. There is no constructive trust of the wife's property for the child, as the wife would perpetrate no fraud if she left her property by will or disposed of it by gift inter vivos to someone else, because she has not taken the benefit of the contract. There may, however, be an implied trust. That depends on the true meaning of the contract between the parties as to whether the right of the survivor to make a different disposition of her property was to be lost on the death of the other or only on accepting the benefit of the other's will.

(d) Husband and wife contract that each will leave his undivided share in the house they live in to the other for life, with remainder in fee simple to the University of Alberta. Mutual wills are made accordingly, the wife's will including a gift of all her residuary 
estate to her sister. The wife dies, having made no later will and without revoking the contractual one. The husband disclaims his life interest under his wife's will, with the result that it would pass under the wife's residuary gift to her sister. There is a trust for the University of Alberta, as the contract would otherwise be totally defeated by the husband's disclaimer. The university has an accelerated right to the wife's share, and is entitled to the husband's share on his death.

The start of it all was Dufour v. Pereira, 56 where the husband and wife made a joint will giving each other life interests in property and giving remainders over. Lord Camden L.C. would not allow a contrary will made by the surviving wife after the death of the husband to defeat the remaindermen, and a trust was enforced on her property. That was a case in which the survivor's property, not obtained under her husband's will, was bound to give effect to the remainders of the joint will which had been contracted for. In Lord Walpole v. Lord Orford, Lord Loughborough L.C. said of Mrs. Rancer: ${ }^{57}$

Suppose she had rejected instead of proving the will of her husband, and had property distinct from that subject to the operation of this contract, and an attempt had been made to bind her by it: I do not apprehend, that Lord Camden would have said, that merely by the chance of her surviving she a feme covert would have been bound by the contract with her husband. I was Counsel in that case; and remember particularly the argument. ...

Allowing that to be correct, for then the remaindermen would at least have had the husband's property straight away, it does not follow that in every case the survivor will be allowed to get away with no trust of his property merely by refusing to accept property from the other testator's estate.

So far as the Canadian cases are concerned, an early one is $R e$ Hackett, ${ }^{58}$ where husband and wife made a joint will (in pursuance of a contract inferred from the terms of the will). It is not clear whether all their property, which is what the will disposed of, was in terms bequeathed to the survivor for life or absolutely, and there was either a remainder or bequest by the survivor of all the property to Mary. The husband died, and the wife took under his will. Years later, the wife made a new, completely different, will, six months after which she died. Rose J. held that Mary was a beneficiary under a trust, which took effect on the wife's acceptance of the benefit of her husband's will, of whatever remained at the wife's death of property which, at the time of the contract, belonged to the husband or the wife. That is interesting from several points of view. First, the date of the trust of the wife's property is based on the wife's acceptance of benefits (fraud giving use to a constructive trust if she takes the benefit and avoids the burden). From that it is implied that the wife could have sloughed off the restrictions on her testamentary freedom by disclaiming her husband's property: again to some benefit of the remainderman if the wife was given a mere life interest by the husband's will, for Mary would then have taken the husband's estate immediately; but if the husband's property was left to the wife absolutely, her disclaimer would only have benefited Mary if Mary were his sole next of kin and, if she was not, the trust should have

\footnotetext{
at Supra, n. 49

57 Supra, n. 42 at $417-418$

SN (1927) 32 O.W.N. 331.
} 
arisen on the husband's death. Thirdly, the trust property is identified in such a way as to give a complete power of disposal of it inter vivos, so there was a true floating trust for purposes of floating away. The wife was cul down, on taking under her husband's will, to a life interest in the property she had then and had owned at the date of the contract, plus a general power of appointment over it inter vivos but not by will. On the other hand, there was no floating in, as the trust property did not include anything the wife acquired after the contract (unless she took an absolute interest under her husband's will, which interest did not float in but was part of the trust property from the inception of the trust). Re Payne, 5: a decision of Masten J.A. from which an appeal was dismissed, ${ }^{60}$ is a similar case except that the husband was the survivor.

In Fie Skippen, ${ }^{61}$ a British Columbia case, husband and wife, in pursuance of a contract, made mutual wills, each testator leaving a life interest in the property to the other, with power to use the capital, and remaincler to their daughter. The wife died, the husband took under her will, and later he died without having used any of the capital but having made a new, different, will. It was held that the husband had held on trust for: the daughter. Coady J. did not indicate what the trust property was, but presumably there was no trust of the wife's property because the pow'er of appointment over capital did not enhance the husband's interest in that from a life interest to something bigger. As to his property' not derived from the wife, he was presumably cut down to a life interest in that, with a power of appointment over the capital, as from the date on which he accepted the life interest under his wife's will.

In $R e K e r r,{ }^{62}$ husband and wife, in pursuance of a contract, made a joint will, that the whole pooled estate of both of them should go to the survivor for life, with remainders over. The will contained a detailed list of what "We have in our estate at this date Feb. 15th, 1935. . ." The wife died, and the husband took his life interest under her will. Some years later, the husband remarried; a couple of years after that he made a new, quite different, will; three weeks later he was dead. Schroeder J. held that all the estate of husband and wife governed by the joint will was held on trust, as from the acceptance of the benefit of the will by the husband, to give effect to the remainders. That must mean that the husband's property was held on a constructive trust. He could not be a trustee of the property he got from his wife, because that was only a life interest. He was reduced, beneficially, to a life interest in his part of the pooled estate, but in view of the way the trust property was itemized and pooled in the will, it did not include such other items as property acquired by the husband after his wife's death. ${ }^{63}$

The joint will under the contract of the husband and wife in Pratt $\mathrm{v}$. Johnson" ${ }^{64}$ gave all the property of each of them to "be held by the survivor during his or her life to use as such survivor may see fit." There followed remainders over of "our property both real and personal" on the death of the survivor. The husband having died, the wife took all the property and later made a new, different will. The Supreme Court of

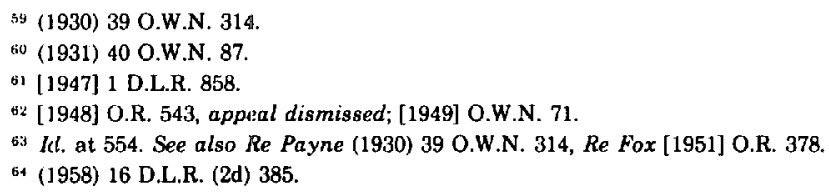


Canada held by a majority (the dissenting judges having held there was no contract) that, on the wife's death, there was a trust for the remaindermen under the joint will of all the property she owned then. It seems that that must have been a floating trust which came into existence not later than the wife's acceptance of her husband's estate, by virtue of which she had a life interest in the property she took under the will, and also in any other property she would, but for the trust, have owned absolutely, together with a general power of appointment inter vivos over the capital. Locke J., with whom Kerwin C.J.C. and Martland J. agreed, said: ${ }^{65}$

It appears to me to be quite clear from the terms of the joint will and from the evidence
supplied by the [widow's] first affidavit that Johnson [the testator] and his wife
intended that upon the death of one of them the survivor should enjoy the use of both
of the estate of the survivor and of the deceased in his or her lifetime but that, upon
the death of the survivor, what then remained of the estate in the hands of the
survivor should be divided equally among the five named beneficiaries. It seems to me
to be impossible to sustain an argument that the right of the survivor to use the entire
estate gave to such survivor the right to deal with it by will in a manner in consistent
with the [provision for remainders in the joint will].

In Re Gillespie, ${ }^{66}$ again, husband and wife made a joint will in pursuance of a contract, the will providing for property to go to the survivor for life, with remainders over. The wife died, and the husband took her property under the will. Years later, he made a new will with different dispositions, and years after that he died. The majority of the Court of Appeal (Laskin J.A. dissenting on the ground that no contract had been proved) held that all the husband's property, or at least that which he had acquired up to the time of his wife's death, became a subject to the trusts of the joint will (i.e. to be held for him for life with remainders over) either when the wife died or when the husband took the life interest in her property.

"The effect is, I think," said Dixon J. in Birmingham v. Renfrew ${ }^{67}$ "that the survivor becomes a constructive trustee and the terms of the trust are those of the will which he undertook would be his last will." The crucial point is that the terms of the trust are the terms of the will. They will indicate what the trust property is, when the trust is to commence, and what the beneficial interests and powers relating to them are. The cases cited so far in this section have all been instances where a life estate or interest has at some stage been mentioned or implied. If the survivor is only to take the other testator's property for life, the one thing that is clear is that the survivor is not a trustee of what he takes under the will of the other. He may or may not become a trustee of some other property. That depends on the terms of the will. The following are the likely possibilities:

(i) The mutual wills govern all the property of both testators, whenever acquired: the survivor's property at the inception of the trust (the death of the other testator or the acceptance by the survivor of a benefit under the will of the other) and property he subsequently acquires (on acquisition) is held by him on trust for himself for life, with remainder (subject to any express or implied power of appointment inter vivos over the capital) on trust for the remaindermen under the joint will.

65 Id. at 390 .

i.it [1969] 1 O.R. 585.

67 (1937) 57 C.L.R. 666 at 683. 
(ii) The mutual wills govern all the property of both testators at the clate of the death of the first to die: the trusts of the survivor's property at that time are as in (i), but property he subsequently acquires is not subject to the trust.

(iii) T.he mutual wills govern all the property of both testators which they own at the date of making the mutual wills and which they still own at the death of the first to die: the trusts of the property the survivor owns at both dates are as in (i), but property acquired by him after the mutual wills are made is not subject to the trust.

(iv) The mutual wills govern specified property of both testators (e.g. one testator's house and the other's jewellery, itemized and identified): the trusts of the survivor's specified property are as in (i), but no other property is subject to the trust.

(v) Variations in (i) to (iii), which do not affect the principles, could be that, instead of all the property it is residuary property after specific or pecuniary gifts, or all property of a class (e.g., all the real property), which is governed by the mutual wills and hence subject to the relevant trust.

(vi) T'he mutual wills govern only what each testator owns when he dies: the survivor is subject to no disability as to dealing with his property inter vivos, but if he changes his will all the property he dies owning will be held by his personal representatives on trust for those entitled under the mutual wills. Conceptually this can only be expressed by starting the trust at the death of the first to die, or on the acceptance by the survivor of property under the other testator's will, and regarding the survivor as holding all his property (what he owns at the inception of the trust and what he acquires later) for himself for life and, subject to a general power of appointment over the capital, with remainder on trust for the persons entitled under the mutual wills.

The precise nature of the floating trust in any case cannot be spelled out without regard to the survivor's power of appointment over the capital, or, in other words, power to dispose of the trust property so as to override the remaindermen's interest in it, which is the subject of a later section of this article. Suffice it to say, at present, that, in the absence of an express power a limited power will be readily implied, so as to provide at least for: the survivor's support, if the trust is of all his property at the inception of the trust and subsequently acquired. At this stage it is necessary to turn to the restriction of the survivor's powers of testamentary disposition where the mutual wills purport to leave the property to the survivor "absolutely" and to leave the survivor's property at his death in some specified way.

In Re Oldham, ${ }^{68}$ where the wills of the husband and wife each gave property to the other absolutely, with the same provisions as to what was to happen to the property if the other died first, Astbury J. held there was no trust because there was no contact that the disposition of the property on the survivor's death should be unalterable by the survivor. The learned judge said: ${ }^{69}$

68 $[19: 35] \mathrm{ch} .75$.

69 Id. at 87 . 
If the spouses intended to do what the plaintiff suggests [i.e., bind themselves to stick to the provisions in the reciprocal wills], it is difficult to see why the mutual wills gave the survivor an absolute interest in the whole of the property of the one who died first.

And he remarked ${ }^{70}$ that a great difference between Dufour v. Pereira and Re Oldham was that in Dufour v. Pereira the capital of the trust property was secured in fact by the life interest only being given to the survivor. With respect, it is quite easy to see why parties who intend an unalterable arrangement would purport to give an absolute interest to the survivor: to make it plain that the trust is a fully floating one in the sense that there is meant to be no inroad on the survivor's right to deal with his own property, and that which he takes under the will of the other testator, inter vivos. That is no evidence that there was no contract: it is evidence, if there is a contract, of what its terms are. The terms are that a trust arises (on the death of the first to die or on the acceptance by the survivor of property under his will) of the property of both parties which is governed by the contract by virtue of which the survivor holds all that property on trust for himself for life, with remainder, subject to a general power of appointment inter vivos by the survivor, on trust for remaindermen specified in the mutual wills. In Dufour v. Pereira the express giving of life interests only made the capital of the trust property more secure in fact in one sense: that the survivor's power of inter vivos disposition so as to oust remainders was more limited.

Re Green ${ }^{71}$ shows that mutual wills giving what appear to be absolute interests can, if there is an appropriate contract, give rise to a trust (so that the survivor in reality has a life interest with or without some power of appointment) and that the terms of the trust are those of the agreement effectuated by the mutual wills. There are the agreement between the husband and wife (recited in the husband's will) was that each would leave all his property to the other absolutely and that the survivor would provide by will for the carrying out of wishes expressed in the will of the first of them to die. Those wishes were mainly to divide the survivor's estate into moieties, one moiety representing the survivor's own property and the other representing property passing to him under the other testator's will, the two moieties being dealt with in different ways. The parties made wills in accordance with their agreement. The wife died, and the husband succeeded to all her property. Some years later the husband remarried and made a new will with different provisions. When one died, Vaisey J. held that the husband's estate was to be divided into two moieties, one held on trust to be dealt with in accordance with the mutual wills and the other to go in accordance with his last will. That means that there was a floating trust of an undivided half share in the husband's property, which is rather unusual but quite in order if that was the intention of the parties. The learned judge said:72 "... the only difficulty I feel is whether effect ought to be given to the whole of the [earlier] will, or only to that part which relates to the moiety which he has allocated to and associated with his [first] wife." And later: ${ }^{73}$

On the whole, although the point is difficult, I am of opinion that the arrangement

\footnotetext{
70 $\mathrm{Id}$. at 88 .

7 [1951] Ch. 148 .

i. Id, at 154 .

$73 \mathrm{Jd}$. at 155 .
} 
was cne which is binding in equity upon what is called the wife's moiety, and having regarit to the form of the clause in the first will, I think that the true solution is this: that the husband's moiety was his own personal property to do as he liked with; and, if he chose after his second marriage to make other provisions as regards that moiety, he was at liberty to do so. It is not a very easy point, and it may be regarded as open to doubt.

In fact, it seems more likely that both moieties were intended to be bound, and that therefore the husband's moiety should have been subject to the trust; it would be strange that rights of remaindermen should be affected by the accident of which party to a contract for mutual wills died first. Both parties' property was held to be subject to the trust, despite the expression of the gift to the survivor as being absolute (if it was) in Re Hackett ${ }^{74}$ and Re Payne. ${ }^{75}$

In Crichton v. Public Trustee, ${ }^{76}$ a New Zealand case, where there was no contract that the arrangement should be irrevicable, the mutual wills were in artless terms, but the reasoning (though not the decision) was even more so. Although the wife died first, it is the husband's will which is quoted here because the wife's, though known to be in reciprocal terms, was not available:

I givis rise, devise and bequeath unto my Wife Cathrine Ann Crichton. All property And other Efficts [sic] (If any) and at her Death. If any property or other Efficts [sic] Be left: to be equally Divided between my son Cyril Crichton. \& (Erick Gordon Peebles.) \& (Arthur Stanley John Peebles). The two sons of My present Wife by her first Husband.

The wije changed her will before she died and the husband's action was an attempt to enforce the remainder in accordance with the earlier will. The wife had been better off than the husband, who wanted to get something for his son. That there was no contract that the arrangement was not to be revoked, or not to be revoked by the first party to die, would have been a good enough reason for the husband to fail. Even if there had been a contract, the husband could not have recovered damages for his son's loss of the remainder; and specific performance was not appropriate. Unfortunately, Reed J. added another, erroneous, ground. Looking at it again through the mirror, as if the husband's will had been in issue, he said: ${ }^{77}$

The gift to the wife is in my opinion an absolute bequest. No doubt the plaintiff in drawing the will intended that the wife should have only a life interest with remainder to thi named children. But the provision that the children should receive only such property as should be left after his wife's death is void for uncertainty, and no trust is create:d.

Now the law is clear, that the job of the court is to construe the will to ascertain the testator's intention and, if that can be done, to ensure that effect is given to that intention if it is lawful. The intention was clear, and Read J. stated correctly. It is obvious that the testator intended his wife to have a life interest and a general power of appointment inter vivos, and that he intended a gift in default of appointment to the remaindermen named. He might not have known how to spell it, but he knew what he wanted. ${ }^{78}$

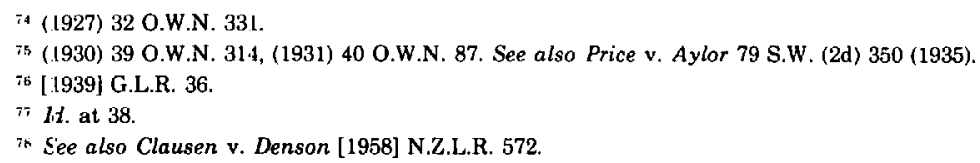


The question of whether mutual wills can ever give rise to a trust before either testator dies is related to that of whether either testator can make a disposition inter vivos of the property covered by the arrangement. The wills alone cannot give rise to a trust before the first testator dies, because a will speaks from death, but the contract between the testators may. In view of the authorities, it is very unlikely that the courts will imply a trust at any date before either testator dies (though presumably the contract could create an executory express trust) in view of their reluctance to imply that the first testator to die is inhibited from changing his will. Any restriction on disposals inter vivos while both testators are alive was rejected by counsel for the plaintiff in Lord Walpole v. Lord Orford, ${ }^{79}$ by the majority of the court in Re Salisbury's Estate, ${ }^{80}$ and by the whole court, the New York Supreme Court, Appellate Division, in $R e$ Glen. ${ }^{81}$ In that case, in pursuance of a contract, husband and wife made a joint will by which each testator left four-fifths of his residuary estate to the survivor. After that, the husband opened a joint bank account with his brother. The husband having died, the brother and the wife both claimed the balance of $\$ 4,234.91$ of the bank account. The brother got it. McAvoy J., giving the judgment of the court, said:81a

The contract [for the irrevocable joint will] has been fully executed by the decedent.
Furthermore, it did not give the [wife] any interest in or control of the decedent's
property during his lifetime, or restrict in any way his right to use or dispose of it as
he might wish while he lived. Assuming that the decedent opened the joint bank
account with the design and intent to reduce the amount his wife would receive under
his will, still such design and intent would not make the opening of said account a
fraud on her.

It might be different if the contract related to specific property, but it would be the contract, not the will, which created the obligation. The question is the true meaning of the contract and, if a trust is to be found, whether the contract is one of which specific performance can be ordered. A will cannot create a trust inter vivos, though it may be evidence of the terms of a contract relating to it.

Bringing the trust into existence on the death of the first testator to die is supported by Re Hagger ${ }^{82}$ and Williams v. Williams, ${ }^{83}$ and rejected by $R e$ Fiegehen. ${ }^{84}$ In Re Hagger a joint will made by husband and wife, which stated they had each agreed not to revoke it unilaterally, gave a life interest in the property to the survivor with remainders over. The wife died, the husband took his life interest in his wife's property, and then he made a new will disposing in a different way of "everything of which he was able to dispose" (a quotation from the law report, not the will). When the husband died, three remaindermen who had been alive when the wife died were dead, and the question was whether their estates were entitled to what had been left to them by the husband in the joint will. Holding that they were, Clauson J. said:85

To my mind Dufour v. Pereia decides that where there is a joint will such as this, on

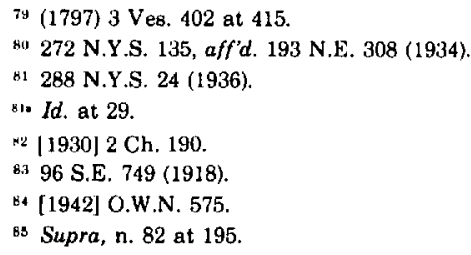


the disath of the first testator the position as regards that part of the property which belongs to the survivor is that the survivor will be treated in this Court as holding the property on trust to apply it so as to carry out the effect of the joint will.

And leiter:"86 "So far as the husband's interest in the property is concerned the will operated as a trust from the date of the wife's death." Now the husband had accepted his wife's property, not disclaimed, but the identification of the exact date on which such a trust commences is obviously important for the estate of a remainderman who dies between the death of the first testator and the acceptance of that testator's property by the survivor. It is submitted that the correct starting date for the trust depends on the contract of the parties and that if the contract does not, expressly or by implication, make it start on the death of the first testator to die, the trust comes into existence when the survivor accepts the other testator's property, but then relates back to the death of the other testator. In the circumstances of Re Hagger it is difficult to believe that there would have been any trust if the husband had disclained the life interest under his wife's will, but as he accepted it the rights of remaindermen should be governed by the wife's death, for that is the date the husband's life interest began and the rights of remaindermen should not be affected by the accident of when the husband decides to accept or disclaim. In 1797 Hargrave $^{87}$ pointed out the close relationship between mutual wills and secret trusts, and the significance for both of the death of the donor. In Re Fiegehen the facts were unusual. They were analogous to those of Re Hagger, except that the wife was the survivor and the remaindermen whose rights were in issue did not die, but were a society which became illegal after the husband died and was illegal when the wife made her new will not leaving them anything and when she died. Rose C.J.H.C. held that there was no trust for the successors in title of the society. That seems to be a decisior as to public policy rather than the construction of the contract. The date of the death as the outset of the trust without waiting to see what the survivor does seems to be the appropriate choice: (i) where the contract expressly so stipulates; (ii) where disclaimer by the survivor would result in the remaindermen getting nothing under the will of the first testator to die; and (iii) where the wills leave nothing to the survivor.

Support for the absence of any trust unless the survivor accepts property under the will of the other testator seems to come from Dufour v. Pereira ${ }^{88}$ itself. Acts of affirmation of the contract by Mrs. Camilla Rancer after her husband's death including taking possession of all his personal estate and enjoying her life interest in it, were expressly made by Lord Camden a ground for holding that she had bound all her property by a trust. Lord Loughborough, in Lord Walpole v. Lord Orford, "19 was emphatic that that was the true basis of Dufour v. Pereira. In Denyssen v. Mostert, ${ }^{90}$ on appeal from the Cape of Good Hope, Sir Robert Collier, giving the advice of the Judicial Committee of the Privy Council, said ${ }^{11}$ that the widow in Dufour v. Pereira, by taking the life interest, bound her assets to make good all her bequests in the mutual

\footnotetext{
ab It. at 195-196.

872 Juridicial Arguments 286-299.

as (:769) Dick. 419.

s9 $(.797) 3$ Ves. 402 at $417-418$

90 (.872) L.R. 4 P.C. 236.

9) Lit. at 253 .
} 
will. In Re Hackett,92 Rose J. based the trust on the surviving wife's acceptance of the benefit of her husband's will. In Dufour v. Pereira and Re Hackett, the survivor was left a life interest by the will of her husband, so if she disclaimed it the remaindermen would take the husband's property straight away and, if that meant there was no trust, they would lose only the benefits of the mutual wills in so far as they related to the wife's property.

With respect to Lord Loughborough and Sir Robert Collier, they may not have been right about the true basis of Dufour v. Pereira. According to Hargrave, ${ }^{93}$ who claimed to have the manuscript of the judgment, Lord Camden, after saying that he could not allow that the survivor might legally recall his contract after the joint lives, continued:

The mutual will is in the whole and every part mutually upon condition, that the whole shall be the will.- There is a reciprocity, that runs throughout the instrument. The property of both is put into a common fund, and every devise is the joint devise of both. This is a contract. If not revoked during the joint lives by any open act, he that dies first dies with the promise of a survivor, that the joint will shall stand. It is too late afterwards for the survivor to change his mind: because the first dier's will is then irrevocable, which would otherwise have been differently framed, if that testator had been apprized of this dissent. Thus is the first testator drawn in and seduced by the fraud of the other, to make a disposition in his favour, which but for such a false promise he would never have consented to.

Later in his judgment, Lord Camden is reported by Hargrave as having said: ${ }^{94}$

... he, that dies first, does by his death carry the agreement on his part into execution. If the other then refuses, he is guilty of a fraud, can never unbind himself, and becomes a trustee of course.

It is only at the end of his judgment, as a separate ground for his decision, that Lord Camden referred to Camilla's acceptance of the life interest under her husband's will: ${ }^{95}$

I have perhaps given myself more trouble than was necessary upon this point; because, if it could be doubtful, whether after the husband's death his wife could be at liberty to revoke her part of the mutual will, it is most clear, that she has estopped herself to this defence, by an actual confirmation of the mutual will,-not only by proving it, but by accepting and enjoying an interest under it.

Hargrave was of the like opinion. ${ }^{96}$

In analyzing what type of trust mutual wills give rise to, it remains to consider what constraints, if any, are imposed on the survivor's right to deal with property inter vivos. There is scant authority from commonlaw jurisdictions in the Commonwealth, but the matter has been fairly fully worked out in the United States of America.

\section{DISPOSALS INTER VIVOS BY THE SURVIVOR}

There being a trust under which beneficial interests in possession are going to exist when the survivor dies, those beneficial interests cannot be thwarted or diminished by the survivor's will. Can they be indirectly thwarted by the survivor's disposal inter vivos of property which: (a) he acquired under the agreed provisions of the will of the testator who died

\footnotetext{
82 (1927) 32 O.W.N. 331.

9:3 2 Juridicial Arguments 308

st Id. at 310 .

95 Id. at 311 .

96 Id. at 299-303, 313-314.
} 
first (the first will not expressly limiting the survivor to a life estate or interest); (b) he owned immediately before the death of the testator who died firsit or has acquired since but not under the agreed provisions of that testator's will?

The first question may be put in this way: if there is a binding arrangement between husband and wife by which each is to leave his property to the survivor, and the survivor is to leave his property to their children equally, and both make wills accordingly, neither will expressly stating that the survivor is to be merely a tenant for life, and the husbancl dies so that the wife takes his property under his will made in pursuance of the arrangement, to what extent, if at all, can the wife dispose inter vivos of the property she takes under her husband's will? When the wife dies, whatever further wills she may have made after her husband's death, there is a trust for the children equally of all the property she owns then and which she took under her husband's will; but are the children also entitled to set up any obligation upon their mother as to how much of that property she shall die holding title to?

At one extreme it may be answered that the wife takes the whole of the husband's property subject to a trust to preserve it all for the children: which is tantamount to saying that, although not so expressed, the true intention of the husband's will was that the property should go to his widow for life, with remainder to the children equally. There is virtually no support in the authorities for such an extreme answer where life interests are not expressly given. In Allen v. Ross, ${ }^{97}$ a mother and daughtel:; in pursuance of a contract between them, made mutual wills by which each left all her property to the survivor and the survivor left all her property to the plaintiff. The daughter died first and the mother succeeded to all her property. Then the mother conveyed all her property, including what had been her daughter's, to the four defendants. The Supreme Court of Wisconsin held that the plaintiff could have the conveyance set aside. The effect of that decision is to treat all the survivor's property as subject to a trust; but it was a case of all or nothing. A ruling that the mother could not give away everything at once sheds no light on what would have happened if the disposal had been of a small proportion. In Re Lender's Estate, ${ }^{98}$ any hint by the Supreme Court of Iowa that the survivor might not have been able to make gifts of property taken under the will of the dead testator was merely by the way in the course of deciding that gifts of other property were valid. In Ralyea v. Venners, ${ }^{99}$ there was a joint will, made in pursuance of a contract between them, of a husband and wife, both of whom had been married once before. Despite their experience of the transitory nature of matrimonial devotion they bound themselves to what turned out to be eternal fidelity. The joint will left all the property to the survivor absolutely and, on the death of the survivor, to the children of each of them equally, in these words two successive clauses:

[i] . . . unto the survivor of us, all and any real and personal property either owned by us ointly or severally for his or her own use and benefit forever. [ii] . . . upon the dea.th of the survivor of us, all the property, real or personal, of the survivor is hereby given, devised and bequeathed to our children, ... share and share alike.

The contract made contemporaneously with the will prohibited the

\footnotetext{
y: 225 N.W. 831 (1929).

4n 18 :N.W. (2d) 536 (1956).

yy 280 N.Y.S. 8 (1935).
} 
parties making any different disposition by subsequent will and also contained a covenant that the parties, and the survivor alone, would not “. . execute any agreement providing for a distribution of his or her property other than contained in the joint will executed simultaneously herewith. ..." The wife died and the husband, by now hooked on the habit, it seems, married a third time. The Supreme Court of New York, in deciding that property he gave to his third wife was held on trust for the children of the joint testators, said the language of the will and the contract 100 "clearly evidences an intention upon both the parties to the joint will and agreement to preserve intact the then owned and later accumulated joint and several property of the parties for the life use and benefit of the survivor, with the remainder over to the then children and stepchildren of both." It was a difficult arrangement to interpret, even perhaps self-contradictory, and one may not agree with the view of the New York court. Nevertheless the principle they applied is sound: that the survivor's power of disposition depends on the terms of the arrangements between the parties. There are degrees of indication of what is to pass on the death of the survivor, from property specifically identified to anything the survivor does not dispose of during his lifetime, by way of all the property, the property, and what remains of it. The interpretation was difficult in Ralyea v. Venners because, on the one hand, the life interest the court held to exist was not easily reconcilable with the words in the will for his or her own use and benefit forever; while anything greater than a life interest would be hard to justify in the light of the covenant, which clearly related to arrangements inter vivos (though agreement providing for a distribution might, perhaps, if the question had arisen, have been held not to cover a small gift or a sale or mortgage of some particular item of property). At any rate, where the answer is given at this extreme there is no floating trust but the survivor takes a life estate or interest in the property of the other testator, with remainder over.

The other extreme is to answer that the wife takes the husband's property with no restriction as to what she does with it except that she cannot dispose of it by will in any other manner than that of her mutual will; which is tantamount to saying that, although not so expressed, the true intention of the husband's will was that the property should go to his widow for life, with remainder to the children equally subject to a general power in the widow to appoint the property inter vivos. There is scant support in the authorities for theis extreme either. In Re Hackett, ${ }^{101}$ husband and wife made a joint will in pursuance of a contract, all their property being given to the survivor and being bequeathed, on the death of the survivor, to one Mary McLennan. The husband died, the wife took his property under the will and she made various dispositions inter vivos of parts of it. Rose J. held the dispositions valid, regarding Mary as the beneficiary of a trust merely of whatever remained at the widow's death. That ought to be the consequence of deciding that that was what the agreement and the will intended. There are some relevant obiter dicta by members of the High Court of Australia in Birmingham v. Renfrew. ${ }^{102}$ Latham C.J. noted:103

\footnotetext{
iov Id. at 11-12.

101 (1927) 32 O.W.N. 331

${ }^{102}$ (1937) 57 C.L.R. 666.

103 Id. at 675-676.
} 
... it is conceded by those seeking to enforce the agreement [for mutual wills] that it does rot have the effect of preventing the husband [the survivor] from dealing during his lifetime with property which he received from his wife, so that any trust which was created can only be a kind of floating trust which finally attaches to such property as he leaves upon his death. Prima facie, where property is given by will or otherwise to a person. and he can do what he likes with it, a gift by the testator or donor of what that person. shall happen to leave at his death does not limit or qualify the absolute gift to him which is the effect of such a dispostion. . . ."

The learned Chief Justice made a useful terminological invention in referringr to the existence of floating trusts; but he was on unsure ground in suggesting that there are prima facie rules for the effect of wills beyond the ascertainment of the testator's intention. The approach he made is rendered suspect by his remark:104

In my opinion, however, it is not necessary for any court at the present day to concern itself with the difficulties in legal theory which the simultaneous recognition of these principles may involve.

That is certainly something it is necessary for courts to concern themselves with. Dixon J., who agreed in general with the Chief Justice's description of the floating trust, said: ${ }^{105}$

\begin{abstract}
It is only by the special doctrines of equity that such a floating obligation, suspended, so to speak, during the lifetime of the survivor can descend upon the assets at his death and crystallize into a trust. No doubt gifts and settlements, inter vivos, if calculated to defeat the intention of the compact, could not be made by the survivor and his right of disposition, inter vivos so as to override the remainderman is not general, but is qualified by the intention of the compact, such an intention must be discerrible. If no intention is apparent beyond what appears to be an absolute gift to the survivor with a gift on the survivor's death of anything that remains, it seems that the power of appointment inter vivos must be general. A trust to leave something, unquantified, unspecified, is too vague to be enforced.
\end{abstract}

Qualifications were discerned without any apparent justification in Price v. Aylor. ${ }^{106}$ There husband and wife, in pursuance of a contract between them, made a joint will leaving all property to the survivor and providing that on the death of the survivor: "All the residue of our property $_{\text {: }}$ real, personal and mixed, including life insurance, which has not heretofore been disposed of by the survivor, ... . we give share and share alike to our nephews. ..." The wife having died, the husband took her property, including a house, under her will. The husband remarried, and conveyed the house as a gift to his second wife. (He later died, having raade a will that purported to leave all his remaining property to the second wife, but that would clearly be subject to the trust for the nephews.) The Court of Appeals of Kentucky held that the nephews could get the property (including the house) back from the second wife. Now the will expressly envisaged disposals inter vivos by the survivor: heretofore does not make sense unless it means before the survivor's death. There is nothing to indicate limits to his power of appointment. The court quoted ${ }^{107}$ with approval earlier judicial pronouncements that the interition of a will or deed overrode ". . . the ancient common-law doctrine that there could be no limitation upon a fee. . ." and that is correct, a.t least as to wills, at least as to meaning that there can be a life estate plus a power of appointment in derogation of a remainder, or a fee subject to a shifting use or condition, and that if the testator's meaning

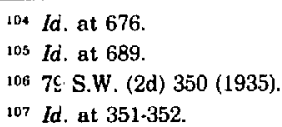


can be ascertained and is not illegal or contrary to public policy the court should give it effect by any appropriate method even if the testator has not himself indicated what that is. But that is not a warrant for finding limitations. It does not require the agility of Houdini to confute the view of Creal C.: ${ }^{108}$

\begin{abstract}
... the conclusion is inescapable that it was the intention of the testator and testatrix that the survivor should take a life estate with full and unrestricted right to its [presumably, the capital's] use and enjoyment and for his and her maintenance and support. Possibly, and if necessary, it might have been used for such purpose even to the extent of exhaustion; but it is equally clear that it was the intention of the parties that whatever might remain at the time of the death of the survivor should pass under the ... [joint] will. . . .
\end{abstract}

Perhaps the survivor was not intended to have an unrestricted power of appointment inter vivos over the capital; perhaps he was not meant to have power to make substantial gifts otherwise than equally to the remaindermen; but there is no clear indication that the power was limited to maintenance and support. Nevertheless, a similar conclusion was arrived at, on similar facts, by the Supreme Court of Tennessee in Ashley v. Volz, ${ }^{109}$ where the surviving husband tried to give away to his second wife a house he had taken from his first wife under the joint will, although the gift to the successful remaindermen was only of "the unexpended residue that said survivor owns. . . ." Another joint will made by husband and wife in oursuance of a contract between them was in issue in First United Presbyterian Church v. Christenson. ${ }^{110}$ There the property was all jointly owned by the parties, so when the husband died the wife became the sole owner by survivorship. The will devised land to the plaintiffs on the death of the survivor. It also provided that, in the event of the husband dying first, the wife ". . . shall at no time sell the real estate" devised to the plaintiffs, "but can sell any of the other real estate. . . ." The widow remarried, after which she gave the land in question to her nieces and nephews. The plaintiffs sued the donees to have the conveyances to them set aside. Eberspacher J., giving the judgment of the Appellate Court of Illinois, said ${ }^{111}$ that the plaintiffs'

action to restrain the disposition of property by the survivor of the joint tenancy must be confined to enforcement of the express limitations embraced in the contract, which will be strictly construed in view of the public policy against conditions in restraint of alienation....

The court held that a restriction on selling did not preclude an inter vivos gift, so the plaintiffs failed. (The fact that the wife took nothing under the joint will did not mean there was no trust, for on the faith of the arrangement the husband had allowed the property to go to her by survivorship when he might, but for the arrangement, have severed the joint tenancy and left his undivided share by will away from her.) The appeal to public policy in this case in aid of a strict construction of limits on the survivor's power of appointment is allying strength to the appeal to the testator's intention. If he does not confine the widow to a life estate or interest; if he does not impose all the limitations third parties contend for on any power of appointment he may give her; he probably means a trust which, within any limits he had indicated, floats at her discretion, so that what is left for the remainderman is, within

IIIK Id. at 352.

106 404 S.W. (2d) 239 (1966).

116) 339 N.E. (2d) 15 (1975).

11 Id. at 19 . 
those limits, up to her. He probably trusts her (whether rightly or wrongly does not matter), and if he gives her property and powers it is not for the court to interfere to give the remaindermen protection the testator cannot be shown to have intended.

The second question may be put in this way: if there is a binding arrangement between husband and wife by which each is to leave his property to the survivor, and the survivor is to leave his property to their children equally, and both make wills accordingly, and the husband dies so that the wife takes his property under his will made in pursuance of the agreement, to what extent, if at all, can the wife dispose inter vivos of any property she may have independently of her husband's carrying out his part of the arrangement? When the wife dies, whether she had a mere life estate or interest or some power over the capital in respect of the property her husband left her, whatever further wills she may have made after her husband's death, there is a trust for the children equally of all the property she has title to then; but are the children also entitled to set up any obligation upon their mother as to how much property she shall hold title to when she dies?

Counsel for the plaintiff asked and answered that question in Lord Walpole v. Lord Orford. ${ }^{112}$ He said: ${ }^{13}$

In Dujour v. Pereira suppose, after the mutual wills were executed, either the testator or testatrix had become embarrassed, and had been obliged to part with some of the proper:y; this sort of instrument must be considered as operating only upon what should be left.

In the event, the point did not have to be decided, but Lord Loughborough L.C. said of Dufour v. Pereira:114

The effect of the agreement was, that the wife had the enjoyment during her life, and limited to that, of all the specific interests: she had a limited power of disposing of part of that property: but all, she had, was upon condition, that she should dispose of her own ploperty, that she might have acquired after his death [what she had before was clearly covered by the contract] (and she did increase it), upon the dispositions of that [joint] will.

On the facts of Dufour v. Pereira, the power the survivor had of disposing of her own may be regarded as subject to the limit that she must give effect to the remainders in the joint will, which were not of the whole property. That might be the basis for a rule that, in the absence of express power to override the remainders, the survivor, when bound by a mutual will arrangement, may dispose of her own property but not so as to defeat the arrangement. If that is right, she would seem to have settled her own property on herself for life either in so far as it is agreed that it shall be disposed of under the contract for mutual wills or as to all her property, after-acquired property coming into the settlement, subject to a power of appointment, unlimited as to objects but not to be exercised so as to prejudice the remaindermen. That is largely how the cases have gone, but some other limits on the survivor's power of disposition have been suggested while some limits to the control of it at the instance of remaindermen have also been put forward.

Cases where the matter is expressly dealt with by the contract between the parties to make mutual wills show that the first recourse is to their intention. In Fourth National Bank v. First Presbyterian

\footnotetext{
112 (1'797) 3 Ves. 402.

II: Id at 415

114 Id at 417
} 
Church, ${ }^{115}$ husband and wife, in pursuance of a contract, made mutual wills, each giving property to the survivor for life with remainders over. The wife died and the husband took under her will, by which the husband was "to have the right to sell, exchange, lease and dispose of any part and all of said property, but not by will" (except for disposal by will in accordance with the agreement between the parties as to how property then still owned by him was to go on the death of the survivor). The widower contracted to contribute $\$ 100,000$ towards a memorial to his wife. After his death, the remaindermen claimed it back. By a majority of the Supreme Court of Kansas, they failed. There may have been three separate grounds for that decision. First, the express power of disposition of the property covered by the agreement (his own and the capital in which the husband had a life interest under his wife's will) was unrestricted. That seems to be what Johnston C.J., giving the judgment of the majority, said first. ${ }^{116}$ It means that the husband had a life interest in everything and a general power of appointment inter vivos over the remainder. Then the learned majority judges noted:117

It may be said that the trust did not become effective until after the memorial contract was made. Under the will, it was not to become effective until the death of both of them.

Perhaps that is another way of saying the same thing, but if so it is a less apt way, for the husband was not expressly given the wife's property absolutely, with a trust of anything he cared to die owning, but was given a life interest with a power to dispose of the capital; his property should have become subject to a corresponding trust when she died or when he accepted a benefit under her will. Then later, the majority seem to have thought there might have been restrictions on disposition which the husband had not infringed. Johnston C.J. said:118

Some of his dealings may have turned out to be improvident or unprofitable
investments, which tended to reduce the estate, but if made in good faith, these would
not have operated to destroy the validity of the contracts he had made with others. He
had a right to use money in keeping with his station in life and circumstances, and the
right to meet the ordinary social and civic demands in the community. The desire to
devote part [about two-thirteenths] of his means in erecting a memorial to his wife was
a natural and honorable one. ...."

They were probably not saying restrictions on the husband's power of appointment inter vivos could easily be imported into its terms, so widely were they expressed, but only that if any restrictions could be imagined they did not comprise what he did. The reference to good faith may indicate that what they thought the husband might not be able to do was to dispose of property with the main motive of diminishing what the remaindermen would come into. A later case in the Supreme Court of Kansas, National Life Ins. Co. of Montpelier, Vt. v. Watson, ${ }^{119}$ seems to be one which really did involve a trust of the survivor's property arising on his death, so that there was no power of appointment before then whose terms needed investigation. The husband and wife there made a joint will, in pursuance of a contract, each of them giving their real property "of which we or either of us may die seized or possessed" to the

1157 P. (2d) 81 (1932).

116 Id. at 83 .

117 Id. at 84 .

IIN Id.

I 44 P. (2d) 269 (1935). 
other foir life. Subject to the life estates, they gave all "such" real estate to their children equally. The wife died and, having taken is life interest in her realty, the husband mortgaged some of his own. It was held that the mortgage was not subject to any claims of the children. Dawson $J$. said that the husbaind: ${ }^{120}$

did not bind himself not to alienate or dispose of any of his property during his life as his own wants, needs, or convenience might require. When [he] joined in the execution of the mutual and reciprocal will of himself and his first wife, he did not therby intend to disable himself to exercise dominion over his own property.

(Anyway, the mortgagee was a bona fide purchaser of a legal estate for value without notice of any trust for the children.) The case is another illustration of the principle that the terms of the trust, including when it is to arise and what property is included in it, are to be derived from the contract between the testators and the wills giving effect to it.

Those two Kansas examples are: (i) of a completely general or very wide power; and (ii) of the continuation of the free alienability that goes with continued beneficial ownership. Instances can also be found of limited express powers. In Heller v. Heller, ${ }^{121}$ in pursuance of a contract, the husband and wife made a joint will of community property. The will provided that, after the death of both testators, ". . . all of the then remaining property ... shall be equally divided between our children. ..." If nothing more had been said, that would appear to create no trust until the survivor died, i.e., the children would be entitled only to what was left in his ownership then. Only the power of testameritary disposition of the survivor would be restrained. But the will also stated: "The survivor ... shall have the right to sell or otherwise dispose of any part of our community property and invest the proceeds of such sale or disposition as he or she may think best." The husband died first and the wife took over the property. Years later, she gave part of the land to her son by conveyance inter vivos. After the widow died, that conveyance was disputed. Pleasants C.J., giving the judgment of the Court of Civil Appeals of Texas, held the conveyance to the son valid if it was in consideration of services rendered and to be rendered by him to his mother in managing the land, which included a farm, fol: the mother could have sold property to raise money to pay a manager; but void if: ${ }^{122}$

\footnotetext{
... the transaction was manifestly an attempt on the part of Mrs. Heller [the widow] to give preference to one of her children in the disposition of the community estate held in trusi: by her. ...
}

And the court sent for trial the issue of which it was. In First United Presbyterian Church v. Christenson, ${ }^{123}$ already referred to in connection with the survivor's power to dispose of property that passed to her on the deatla of the other testator, the decision of the Appellate Court of Illinois and the principle on which it was based also applied to the other property of the survivor.

Similarly in Ralyea v. Venners, ${ }^{124}$ also quoted already in that

\footnotetext{
1211 Id. at 270. See also the remarks of Graves J. in the Court of Civil Appeals of Texas in Wallace v. Peoples 89 S.W. (2d) 1030 at 1032 (1936).

12123 S.W. 870 (1921).

122 Id. at 872. See also the decision of the Supreme court of Indiana in Sample v. Butler University 4 N.E. (2d) 545 (1936); 5 N.E. (2d) 888 (1937).

12:1 33C N.E. (2d) 15 (1975).

124 28C N.Y.S. 8 (1935).
} 
connection, the court interpreted the arrangement in relation to all the survivor's property, both that derived from the testatrix and property he owned during her lifetime or acquired after her death. The survivor would appear, by the arrangement with his wife, carried out by executing the joint will, to have settled all his then and after-acquired property upon himself for life, with remainder to the children, at least from the date he accepted property (also apparently for life estates and interests only) under his wife's will.

Courts in the United States of America have also been called on to consider the validity of dispositions inter vivos by the survivor in cases where the arrangement between the testators made no express reference to his powers of dealing with the property otherwise than by will. The approach they have used is based on the idea of preventing fraud as enunciated in Dufour v. Pereira, or not allowing the trust, which could not be defeated directly (by a new will), to be defeated indirectly (by disposal inter vivos). As long ago as 1906, the Supreme Court of Missouri, in Bower v. Daniel, ${ }^{125}$ indicated how the courts would control the survivor. In that case, husband and wife, in pursuance of a contract, made a joint will by which each left his property to the other for life with remainders over. The wife died, and the husband took under her will. Later, he made voluntary conveyances (not to the remaindermen in accordance with what they would get under the joint will) of land not deriving from his wife, reserving life estates to himself. The husband having died, it was held that the transferees under the conveyances held the land on trust for the remainderman named in the joint will. Now this was not an arrangement under which the husband's property at the time he accepted benefits under his wife's will, or at any earlier time, became subject to a trust by which he settled property on himself for life with remainder to the beneficiaries under the joint will. It was a floating trust to attach to the husband's property only in respect of what he owned at his death. Accordingly, he retained some powers of disposition inter vivos so as to take the property out of the trust. Burgess P.J., giving the judgment of the court, said: ${ }^{126}$

Conceding the joint will as embracing only such property as each (the husband and wife) had at the time of his or her death, and that the testator might have thereafter sold and disposed of his property in good faith, or 'given it away, as said in Van Duyne v. Vreeland [12 N.J. Eq. 142, not a case of mutual wills], . . it was a fraud in fact and in law for him to convey it to others,voluntarily and without consideration, reserving to himself a life estate, and in this way make a disposition of his property ... different from that for which he contracted with his wife in the joint will. There can be no question, we think, that the testator executed those voluntary conveyances and made the subsequent will for the purpose of defeating the joint will, which acts were, in our opinion, ineffective for that purpose.

The principle seems to be that the existence of a floating trust, from its inception until it crystallizes, precludes dispositions made for the purpose of defeating the future beneficiaries. The impression that the purpose is to defeat the beneficiaries is heightened by the fact that the husband did not purport to part with the whole of his interest in the land conveyed until his death-the date of the trust crystallizing.

In Rastetter v. Hoenninger ${ }^{127}$ too, husband and wife, in pursuance of a contract, made a joint will by which each left his property to the other

12595 S.W. 347.

126 Id. at 359 .

127108 N.E. 210 (1915). 
for life, with remainder over. On the death of the survivor, the property was to go to the children equally (or to grandchildren if their parent was dead when the surviving testator died). The wife died and the husband took under her will, and their son died. After that, the surviving husbancl paid for land to be conveyed to his daughter, the purchasemoney being of doubtful origin (i.e., it was not known whether it derived from the wife's estate, in which the husband had only a life interest). After the husband's death, his dead son's children impugned the transaction. Miller J., giving the judgment of the Court of Appeals of New York, said:128 "Each, during his life, remained the absolute owner of his own with all the rights of an owner." But: "The survivor could not after accepting the benefits of the agreement make a gift in the nature, or in lieu, of a testamentary disposition or to defeat the purpose of the agreement." A new trial was ordered to determine whether the land was bought with money from the wife's estate, or was given to the daughter in contemplation of the husband's death or given to avoid performance of the algreement with the wife, in any of which cases the daughter would hold it on trust. (In Allen v. Ross, ${ }^{129}$ already referred to in connection with the survivor's power to dispose of property that passed to her on the death of the other testatrix, the decision of the Supreme Court of Wisconsin also applied to the other property of the survivor.) In Re Lencler's Estate ${ }^{130}$ husband and wife, in pursuance of a contract, made mutual wills, each leaving to the other or, if the other were the first to die, to certain named people, the residue "of the property I may own at the time of my death ..." The view of the Supreme Court of Iowa was that the surviving wife could make gifts, at least of property she did not derive from her husband's estate, provided they were reasonable, absolute, bona fide, not testamentary in effect and not made for the purpose of defeating the contract or having that effect.

When the arrangement does not relate to all property, residuary property or some other property described by its class, but specifies particular property then owned, the inference is that the trust is not floating, but that the survivor, from the moment the trust takes effect, has no nore than a life estate or interest in that property. The question then arises, not of implied restrictions on the power of disposal of the corpus, but whether there is any, necessarily limited, implied power of disposal. In Schwartz v. Horn, ${ }^{131}$ the Court of Appeal of New York thought, obiter, that there was. In that case, husband and wife, in pursuance of a contract, made mutual wills by which property was left to the survivor for life, and then to be divided equally between their son and daughter. The will of the wife, in pursuance of the contract, referred specifically to her "personal property" and "home at 55 Mile Square Road, Yonkers, New York" as going (at the death of the survivor) to the children in undivided shares. The husband died first, and the wife took under his will, at which point, if not earlier, the home became subject to a binding obligation, which amounted to a trust for the wife herself (the owner of the legal fee simple) for life, with remainder in fee simple to the children in equal shares. Had the wife any implied power of appointment of the fee simple remainder so as to override the children's interest

\footnotetext{
128 Id. at 212.

124 22; N.W. 831 (1929).

1:3 78 N.W. (2d) 536 (1956).

131 31 N.Y. (2d) 275 (197\%).
} 
under the trust? It was alleged that some years after her husband's death, she conveyed 55, Mile Square Road to her son's son Jeffrey by way of gift, but continued to live there till shortly before she died (yet more years later). It was held that the premises were subject to such an equity that any implied power there was did not embrace what the surviving testatrix was alleged to have done. Fuld C.J., giving the judgment of the court, said:132 ". . . the surviving testator is not free to make an inter vivos gift to defeat the agreement." That is minimal and settled. Later he offered some general remarks: ${ }^{133}$

There is, of course, a vast difference between an agreement to bequeath or devise a
specific piece of property-as here-to named individuals and an agreement between
testators that the survivor will leave his entire estate... to particular
beneficiaries. . . it is our conclusion that in the first case, the agreement precludes
an inconsistent inter vivos gift. But this does not mean that the agreement in the other
case-that the entire estate be left to certain beneficiaries-necessarily prevents the
survivor from making a gift during his lifetime, since such a gift would not necessarily
defeat the purpose of the agreement. . . In no instance, however, would a transfer-
whether or not it defeats the purpose of the agreement-be prohibited when the
property or its proceeds are used to meet the daily needs of the surviving testator.

The authorities cited so far are all cases in which the proceedings were taken after the death of the survivor of the two testators. Campbell v. Dunkelberger, ${ }^{134}$ shows that it is not necessary to wait that long. As soon as the survivor threatens a breach of trust (or excessive execution of her power of appointment), the beneficiary in remainder (or entitled in default of appointment) can seek redress. In that case, husband and wife, in pursuance of a contract, made a joint will. The husband devised his hotel to his wife absolutely and the rest of his property he left to her for life; the wife left all her property to her husband for life' and both directed the same remainders over on the death of the survivor. The husband died; the wife took under his will; she sold the hotel. That sale was all right: there was no trust of the hotel. Then she wanted to give away some land not derived from her husband's estate. On taking property the subject of the contract under her husband's will, at the latest, her other property became subject to a trust for herself for life with remainder in accordance with the joint will. The disposition she proposed was not authorized by any implied power of appointment she may have had in defeasance of the remainder over. The Supreme Court of Iowa granted the remainderman an injunction to restrain her from giving away her land otherwise than to the remainderman under the joint will. (She could, of course, have given it away for an estate for her own life.)

The United States courts, it seems, will give whatever remedy is appropriate to enforce the agreement or prevent fraud. The nature of the floating trust so refined in cases of mutual wills may be adaptable to other gifts where donor intends that what shall ultimately go to a remainderman is to crystalize only on the expiry of a prior interest.

\section{THE CHARACTER OF THE FLOATING TRUST}

While many details have as yet been considered in American courts and not in those of Commonwealth countries, it is clear that there is no difficulty in policy or concept, and only surmountable administrative inconvenience

${ }_{132}$ Id. at 279 .

13: Id. at $280-281$.

134 153 N.W. 56 (1915), 
in respect of chattels and money, in construing and enforcing a trust which is to crystallize on death while allowing beneficial enjoyment with limited or unlimited powers of disposition by the legal owner during his lifetime. Uncertainty of subject-matter is no objection, though it may be a relevant factor ir. cases of doubt as to whether a trust was intended or not, so long as the extent of the owner's rights inter vivos can be determined and the property to be affected can be identified when the date of crystallizing occurs. There is a close analogy in that respect between the floating trust and the floating charge. All the terms of the trust, including its date of commencement, depend on the agreement between the parties, and (assuming it is not express) the trust may be implied or constructive as appropriate. If, during the floating stage, the rights of disposal of the legal owner are not absolute, a breach of trust may occur not solely by reason of acts done but also by virtue of the motives with which they are done. There is not repugnancy between the legal owner having rights of enjoyment and disposition and is inability to affect the destiny of the property by a subsequent will: conceptually, the owner can be a trustee for himself for life, have a special or general power of appointment inter vivos, and be a trustee for a remanderman of the property in so far as it is unaffected by a valid exercise of the power. The appropriate type of trust can be imposed to effectuate the intention of the parties by controlling the survivor of the contractors for mutual wills, and also in other types of case, of which the following three are the main examples to come before the courts so far.

(i) A contract by a single testator to leave his property by will in a particular way. In Palmer v. Bank of New South Wales ${ }^{135}$ the testator contracted to leave all his property by will to Mr. and Mrs. Falmer. He did so, but he diminished his estate inter vivos after the contract was made. The High Court of Australia held that the transaction inter vivos was not a breach of trust, that being a matter of the construction of the intention of the parties. But the judgment of Barwick C.J., with which the other judges agreed, makes it plain that the testator could not have made subsequent wills which would effectively have disposed of the beneficial interest in his property away from Mr. and Mrs. Palmer or have so arranged his affairs inter vivos that he would have had the sole enjoyment of his property during his lifetime and that someone other than $\mathbf{M r}$. and Mrs. Palmer would take it on his death.

(ii) A. secret trust created between a single testator and his legatee or devisee. In Ottaway v. Norman ${ }^{136}$ the testator left his bungalow and contents and some money to Miss Hodges. It was alleged that there was a secret trust under which Miss Hodges was obliged to leave the bungalow, the contents here at her death (whether derived from the testator's estate or not) and her money (without prejudice to her unfettered right to spend it inter vivos) to William Ottaway. Brightman J. held the secret trust proved only as to the bungalow and its contents in so far as Miss Hodges acquired them from the testator's estate, but he was prepared to assume that the more extensive floating obligation alleged would have created a valid trust if that had been the intention of the parties.

(iii) A gift by a single testator of property to one person, with a gift over to another person of what the first person has left of it at the time of his 
death. That sort of disposition is the subject of many, apparently conflicting, Canadian decisions, of which $R e$ Walker ${ }^{137}$ and $R e$ Shamus, ${ }^{138}$ both decisions of the Ontario Appellate Court, provide illustrations of diverse appraoches. If the will is held to pass the whole legal title to the first donee, the intention of the testator that the second donee is to take what is left when the first donee dies can be effectuated by the appropriate type of floating trust.

In effectuating parties' intentions, fulfilling legitimate expectations and preventing unjust enrichment, the doctrines of equity do not provide suitably for every occasion; nor are they to be used to carry out a speculative, unproved, intention; but those doctrines are adaptable to a wide variety of circumstances.

$1: 37$ (1925) 56 O.L.R. 517.

138 (1967) 63 D.L.R. (2d) 300. 